\title{
After the Ainu Shinpō: The United Nations and the Indigenous People of Japan
}

\author{
Crystal Porter \\ Australian National University
}

\begin{abstract}
The Japanese Government recognised the cultural importance of their minority Ainu population in 1997. They designed a law to help protect the dying culture of the people; however the government has been less forthcoming to acknowledge indigenous aspects of the Ainu. Ten years after the creation of this law, the United Nations brought forward the Declaration on the Rights of Indigenous Peoples, a declaration to strengthen not only cultural rights, but also land and self-determination rights. Japan voted in favour of this declaration even though Japanese representatives have made mostly negative comments on the declaration.
\end{abstract}

This article explores the significance of indigenous rights in Japan and how the Japanese Government uses the guise of upholding individual rights to ignore indigenous rights in Japan.

\section{Keywords}

Japan, Ainu, indigenous people, United Nations, human rights

\section{Introduction}

For many indigenous people worldwide, distinctive rights have become an important issue. Many have suffered from discrimination, displacement and have poor standards of living. Thus, 2007 was a special year for many people. In September, the United Nations adopted the controversial Declaration on the Rights of Indigenous Peoples. This declaration took more than twelve years to produce and was received by an overwhelming majority of nations. Japan was one of the many countries that endorsed this declaration. ${ }^{1}$ This endorsement came exactly ten years after the Japanese

\footnotetext{
United Nations General Assembly, 'General Assembly adopts Declaration on the Rights of Indigenous Peoples'.
} 
.

Government enacted the so-called Ainu Shinpō (Ainu New Law), an act to protect and promote the culture of Japan's Ainu population.

The Ainu people of Japan consist of a minority group originally from the northernmost areas of Japanese land, as well as the Russian administrated Kuril Islands and Sakhalin. For nearly a hundred years, the Japanese government displaced Ainu people and subjected them to a number of discriminatory practices by controlling Ainu land and education standards. ${ }^{2}$ However, in 1997, the Sapporo District Court recognised the indigenous status of the Ainu under the Constitution and international law; this decision is now known as the Nibutani Dam case. The Nibutani Dam Case ruling and the creation of the Ainu Shinpō initially appeared to be a breakthrough in securing further rights for the Ainu, but these victories have severe limitations.

The Ainu Shinpō aims to diffuse cultural aspects of the Ainu, which is where the law's main shortcoming lies. It makes no reference of other rights, thus having little practical value to the Ainu people. The act also guarantees no collective power and as a result, anyone can use the funds made available to promote Ainu culture. Furthermore, the Act itself avoids any definition of Ainu people and does not give adequate recognition to indigenous status. ${ }^{3} \mathrm{~A}$ mention of indigenousness is written in supplementary provisions of the act but this is not legally binding and cannot be utilised in any manner. Unlike the court, the Japanese government has refused to acknowledge the Ainu as being indigenous. The United Nations has released a report challenging notions of indigenousness in Japan, recommending that Japan take further steps to acknowledge the Ainu. ${ }^{4}$ Despite some progress, little has changed for the Ainu situation. However, as the Declaration on the Rights of Indigenous Peoples has evolved, the Ainu situation needs to be reassessed.

The Japanese government was active in voicing many opinions about the Declaration on the Rights of Indigenous Peoples during its drafting. This article aims to use these opinions to put the declaration in context for the Ainu people. It will look at which aspects of the declaration Japan was strongly opposed to and why. By assessing the government's reasoning, likely outcomes of the declaration in Japan can be gauged. 


\section{The United Nations Declaration on the Rights of Indigenous Peoples}

Since the International Year for the World's Indigenous People in 1993, the United Nations has placed emphasis on introducing some form of declaration to recognise the presence of indigenous people around the world. Such a declaration would not be legally binding but the United Nations encourages states to enact consistent domestic legislation. ${ }^{5}$

Three official drafts have been presented for debate. The United Nations' Working Group on Indigenous Populations (WGIP) presented the first public draft to a United Nations sub-commission for debate in 1995. This effort was directed at having a declaration in force to mark the beginning of the first Decade for Indigenous People, which began in $1995 .{ }^{6}$

Some states found the 1995 Draft Declaration on the Rights of Indigenous Peoples to be too liberal. Thus, a revised draft was presented in 2006. However, the 2006 draft still contained many of the same controversial provisions. Subsequently, two drafts were created in 2007. The final draft was endorsed in September 2007, with Japan being one of the nations in favour of this particular draft. Tellingly, the declaration has been through many changes before its eventual implementation.

\section{The 1995 Draft Declaration}

Individuals, who identify as being indigenous, wrote most of the 1995 Draft Declaration on the Rights of Indigenous Peoples. This original 1995 draft was sent to the SubCommission on the Prevention of Discrimination and Protection of Minorities, where government representatives of member states scrutinised the proposed declaration. Eventually, the Sub-Commission decided that the draft declaration needed to be revised. This was in response to the criticism that came from these government representatives. Japan was one of the strongest critics $^{7}$ as many of the articles contradicted the government's stance on collective rights, which were featured heavily in the $1995 \mathrm{draft}$ declaration. Collective rights form the basis of many essential indigenous rights, selfdetermination being one of the most important.

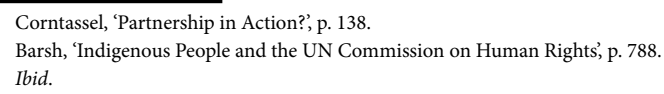


.

Article 3 of the 1995 draft declaration stated that, 'Indigenous peoples have the right to self-determination' and article 31 stated, 'Indigenous people... have the right to autonomy or self-government in matters relating to their internal and local affairs.' ${ }^{8}$ While a clear definition of self-determination is not given, the Japanese representative opposed both articles. The representative argued that these articles would give indigenous people collective political power that is distinct from other Japanese citizens. ${ }^{9}$ Furthermore, the representative declared that collective rights 'cannot be found in international instruments. ${ }^{10}$ In arguing this, Japan seems to be unaware of previous declarations, such as the Declaration on the Rights of National or Ethnic, Religious and Linguistic Minorities that provide for such rights. ${ }^{11}$

In addition to this, the first two articles of the 1995 draft declaration faced objections solely from Japan. The first article provided indigenous people with 'the right to the full and effective enjoyment of all human rights and fundamental freedoms recognised in... international human rights law. ${ }^{12}$ The Nibutani Dam Case is an example of how this could influence the Ainu people.

In that decision, the court considered the Ainu as a minority group and also as an indigenous group. The main dispute in this case was whether a government body had sufficiently consulted Ainu people prior to starting construction of a dam. The Sapporo District Court recognised that land is essential to the culture of the Ainu people. Much of this protection stemmed from indigenous recognition in existing international human rights conventions. ${ }^{13}$ Thus, the court used international law to guarantee the human rights and freedoms of the indigenous Ainu in the Nibutani Dam Case. However, for the Ainu to fully enjoy current human rights, indigenousness became an important issue. The court decision made the connection to which the proposed article 1 was alluding to, that indigenous people have rights under existing law as an indigenous people.

In opposition to this first article, Japan cited the issue of 'collective dimensions of indigenous rights. ${ }^{14}$ This would suggest that Japan is comfortable with individual indigenous rights but has difficulty treating indigenous rights in a collective manner. However, if the Nibutani Dam Case ruling had only considered individual dimensions of rights, the plaintiffs would have needed to assert that their own land was important enough to stop construction of the Nibutani Dam. They would have had no right to

\footnotetext{
8 Sub-Commission on Prevention of Discrimination and Protection of Minorities, 'Draft United Nations Declaration on the Rights of Indigenous People', pp. 8 \& 19 .

9 Barsh, op. cit., p. 800.

10 Ibid., p. 788.

11 United Nations General Assembly, Declaration on the Rights of National or Ethnic, Religious and Linguistic Minorities.

12 Sub-Commission on Prevention of Discrimination and Protection of Minorities, op. cit., p. 7.

13 Levin, 'Kayano et. al v. Hokkaido Expropriation Committee (The Nibutani Dam Decision)', p. 395.

14 Barsh, op. cit., p. 804.
} 
assert any kind of right for Ainu people as a whole, even if this particular land was important for the Ainu community. ${ }^{15}$ As a result, the case would not have been as successful if the Ainu had not been construed as a group. This United Nations debate on the draft declaration was progressing simultaneously as the Nibutani Dam Case; thus, the connections would have been obvious to the Japanese Government.

There were some concerns shared by Japan and other nations. The most important issue was over the definition of indigenous people. ${ }^{16}$ In the debate, Japan was one of many countries that insisted that a definition of indigenousness be included in the declaration. Interestingly, this view was shared by most Asian nations, while the Western nations tended to agree that there were already sufficient definitions in international materials, such as the International Labour Organisations' Convention concerning Indigenous and Tribal Peoples in Independent Countries. ${ }^{17}$

As such, the International Labour Organisation's convention defines indigenous peoples as those 'who are regarded as indigenous on account of their descent from the population which inhabited the country, or a geographical region to which the country belongs, at the time of conquest or colonisation or the establishment of present state boundaries and who, irrespective of their legal status, retain some or all of their own social, economic, cultural and political institutions.' ${ }^{18}$ According to this definition, the Ainu would be considered indigenous. They have long inhabited northern Japan before Hokkaido and surrounding areas became part of Japan in the nineteenth century. The Ainu were also subject to colonisation practices at this time as the Japanese government took land from them and forced the Ainu into a different lifestyle. ${ }^{19}$ However, Japan is not a signatory to the International Labour Organisation's convention and ignored this convention when protesting that international definitions of indigenousness did not exist.

Insisting on a definition in the declaration can only mean that these Asian states wanted one that was different from the current standards. Tellingly, the Chinese representative was vocal in that indigenous people were to be understood as a product of European colonial practices and therefore no indigenous people exist within Asia. ${ }^{20}$ However, by complying with the conventional definitions that currently exist, Japan would have to recognise the Ainu as a colonised indigenous people to whom this declaration could apply.

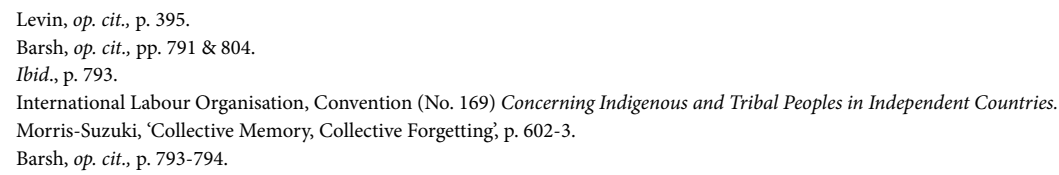


.

From the 1995 debate, it is apparent that the Japanese government did not want to concede self-determination or collective rights due to the individual nature of the Constitution. The representative also appeared reluctant to admit past colonial practices by the government.

After the comments made by the government representatives were noted, the 1995 draft was sent back to the WGIP. Eleven years later, a revised draft was released and Japan continued to present some of the same opinions when the declaration was presented again. Despite this, Japan voted in favour of forwarding the draft to the General Assembly where it could officially be voted in. Investigation of the revisions between the 1995 and 2006 drafts provide an indication of what the Japanese Government was in fact comfortable with.

\section{The Draft Declaration in 2006}

The WGIP made significant alterations between the 1995 and 2006 draft. Japan voted in favour of the draft in 2006 and was part of the majority vote that sent the $2006 \mathrm{draft}$ declaration for consideration to the Third Committee of the United Nations' General Assembly. However, the committee did not approve the draft because of further concerns about self-determination. ${ }^{21}$ Japan refrained from this second vote at the Third Committee and continued to reaffirm its stance on the idea of collective rights.

In the first vote of 2006, which took place in the Human Rights Council, the representative from Japan stood firm on the same point of view that was presented eleven years earlier, asserting collective rights could not be recognised within Japan. ${ }^{22}$

In the 2006 Draft Declaration on the Rights of Indigenous Peoples, collective ideas of self-determination remained intact. ${ }^{23}$ This meant that Japan's continuing argument that collective rights cannot exist within Japan compromised a significant portion of the draft declaration. This is despite the inclusion of a paragraph in the declaration's introduction that, 'indigenous peoples possess collective rights which are indispensable for their existence, well-being and integral development as peoples. ${ }^{24}$ This was not present in the $1995 \mathrm{draft}$ and was perhaps included anticipating such a response. However, as international declarations are subordinate to the national Constitutions, this inclusion is unnecessary for Japan.

\footnotetext{
United Nations, 'Namibia: amendments to draft resolution A/C.3/61/L.18/Rev.1', p. 1 .

Human Rights Council, 'Human Rights Council adopts texts for protection from forced disappearance, rights of indigenous people', p. 8.

Human Rights Council, 'Implementation of General Assembly Resolution 60/251 of March 152006 entitled "Human Rights Council”, p. 6.

4 Ibid., p. 5.
} 
Japan pushed for a definition of indigenous people in the 1995 talks. Without an actual definition, recognising indigenous people may have come down to a single article in the $1995 \mathrm{draft}$, 'Indigenous people have the collective and individual right . . . to identify themselves as indigenous and be recognised as such. ${ }^{25}$ Any question of indigenousness would be solved by self-identification, so any Ainu could potentially assert their individual right to be identified as an indigenous person and could use any definition. In 2006, this particular article was removed from the declaration. Thus, indigenous identification is under government control. While the actual rights afforded aren't entirely different in the 2006 draft, the means of how they are applied are. Therefore, the 2006 draft wasn't as strong as the previous $1995 \mathrm{draft}$.

However, the 2006 draft was rejected by the United Nations' Third Committee, as self-determination was still an important factor in the draft and the nations agreed to review the $2006 \mathrm{draft}$ and look at it again the next year.

\section{The Draft Declaration in 2007}

The Draft Declaration on the Rights of Indigenous Peoples was presented to the General Assembly again in 2007 with many changes made from the previous year.

In May 2007, many African nations put forward their own draft because they believed that self-determination rights in the previous draft could lead to loss of government control and confusion over territorial boundaries. ${ }^{26}$ The 2007 African draft reflects these concerns. Instead of having the rights to self-determination, indigenous people would now be able to 'participate in the political affairs of the state and to pursue their economic, social and cultural development on an equal basis with others.' ${ }^{27}$ This article suggests little change.

Many of the proposed amendments in the 2007 African Draft Declaration on the Rights of Indigenous Peoples allowed states to freely define several important aspects of the declaration. The first such article is in reference to inherent rights of indigenous people, which would have to be respected 'in accordance with the national laws.' ${ }^{28}$ By this, the non-existence of collective rights in the Japanese Constitution is crucial. In addition to this, rights to any form of self-government (that is, self-determination) must also be exercised 'in accordance with the provisions of national laws'. ${ }^{29}$ Again, Japan can

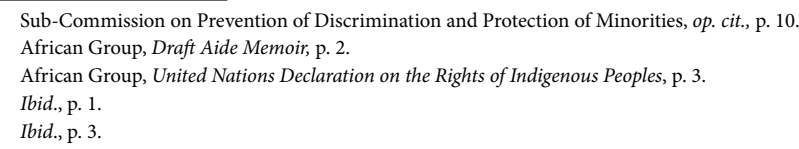


.

use their collective rights argument to deny self-determination. There are several other instances where implementation of the provisions would be subject to laws of the state. Defining indigenous people would have also been placed in the hands of the state.

The African states were concerned that many ethnic groups of people within their nations could be defined as indigenous, so the essential idea of self-determination was problematic for them. ${ }^{30}$ This is addressed at the beginning of their draft, 'Recognising that the situation of indigenous peoples varies from region to region, country to country and from community to community, every country or region shall have the prerogative to define who constitutes indigenous people in their respective countries or regions taking into account its national or regional peculiarities. ${ }^{31}$ This provision would be beneficial to not only these African states but also to the Asian nations who wanted a different definition. Japan, also, could have freely defined what indigenous means in Japan. As the government has not used the ILO definition in the past, it is likely that they would have interpreted the definition of indigenous quite differently.

The African Group draft was revised further before being forwarded to the General Assembly in September. This final draft is a combination of the 2006 draft and the African group draft. As such, under this final draft, nations can take into account the aspects of their region when applying the declaration, ${ }^{32}$ however, this version of the draft stops short of allowing states to define who is indigenous and still has a degree of self-determination. The issue of self-determination, however, has been slightly revised so that, 'Nothing in this Declaration may be interpreted as for any state, person, people, group or person the right to engage in any activity ... which would dismember or impair, totally or in part, the territorial integrity or political unity of sovereign and independent states. ${ }^{33}$ This is important as Japan has territorial issues that concern the Ainu people. Furthermore, the second and final 2007 draft still lacked a definition of what it means to be indigenous.

The second 2007 Draft Declaration on the Rights of Indigenous Peoples was forwarded to the Third Assembly of the United Nations. The revised articles resulted in an overwhelming positive reception, a large change from the 2006 vote. Japan was one of 143 nations who voted in favour of the revised 2007 draft. The United States, Australia, New Zealand and Canada were the only dissenting votes. ${ }^{34}$ This draft is now formally implemented as the final declaration.

\footnotetext{
African Group, Draft Aide Memoir, p. 2.

African Group, Declaration on the Rights of Indigenous Peoples, p. 3

United Nations General Assembly, 'Declaration on the Rights of Indigenous Peoples', Document A/61/L.67, p. 3.

Ibid., p. 12.

4 Asahi Shinbun, '先住民族権利宣言を採択20年以上の議論の末国連 [The Declaration on Indigenous People is adopted at the end of more than 20 years of debates at the United Nations]'
} 
After the vote, the Japanese government delegate confirmed Japan's position that self-determination could not be used to assert that indigenous people are separate from their states of residence nor did it impair the sovereignty of a nation's laws. ${ }^{35}$ Importantly, the Japanese government representative also stated that the right to self-determination in the declaration 'should not be invoked for the purpose of impairing the sovereignty of a State, its national and political unity, or territorial integrity. ${ }^{36}$ This is a stance that had not been previously presented by the government. However, it may have been a point significant enough to warrant a fresh attitude from the Japanese government.

The Japanese government demonstrated a far more positive reaction to the final 2007 draft by voting in favour of it. However, the denial of collective rights and the protection of territorial boundaries indicates that the Ainu may receive little or no benefits from the United Nations developments. This situation has the potential for change if the lack of rights is due more to government attitude than Constitutional strength. Thus, the actual reasoning behind the rejection of indigenous rights will be considered.

\section{Collective and Indigenous Rights}

At United Nations discussions, the Japanese government displayed no intention of recognising many fundamental rights, so it may be asked why the denial of particular rights is so important to Japan. Is it because of the national laws or because of political motives? An analysis of collective rights in international and domestic Japanese law demonstrates the complex relationship between individual and collective rights.

\section{Collective Rights vs. Individual Rights}

Collective rights are a special category of rights that are especially important for indigenous people worldwide. This is due to the nature of how these rights are usually applied and the history that has led to their current status in international law. These rights are collectively held by members of a certain group and cannot be asserted individually. These groups are usually distinct from the majority population in a significant way such as linguistically, religiously or culturally. Thus, for various minority groups, collective rights have become important for preserving culture and resisting discrimination. ${ }^{37}$ Inclusion of this type of right is a relatively recent development as individual rights have

\footnotetext{
Ibid.

36 United Nations General Assembly, 'General Assembly adopts Declaration on the Rights of Indigenous Peoples.

37 Felice, Taking suffering seriously: the importance of collective human rights, p. 22.
} 
.

long been the norm in Western legal systems. Individual rights also feature prominently in the United States inspired post-war Constitution of Japan. ${ }^{38}$

This is a significant difference between Japan's Meiji Constitution and the postwar Constitution. According to the earlier Meiji Constitution, the Emperor granted rights to Japanese citizens as his subjects. Despite the fact that the Constitution was modelled on the Prussian Constitution, the Japanese product differed by excluding notions of individual rights that were otherwise included in the Prussian Constitution. ${ }^{39}$ People were more a collective whole rather than individuals.

The post-war Constitution, however, was based largely on the Constitution of the United States, which has many references to individualism and liberalism. Americans wrote this constitution during the occupation and sought to concentrate on individual rights. ${ }^{40}$ In this constitution, articles refer to rights that belong to Japanese citizens on an individual level and they are held, rather than granted. ${ }^{41}$ In this way, the post-war Constitution is a large shift from the previous Constitution.

Despite this, the Japanese court in the Nibutani Dam Case was able to view individual rights and collective rights as not being mutually exclusive. ${ }^{42}$ Viewed in this manner, individual rights do not necessarily render collective rights invalid in Japan. Despite this, in international forums the Japanese government has continually insisted on their interpretation of the constitution that divides collective and individual rights into two separate categories that cannot exist together. ${ }^{43}$ In doing so, such an interpretation appears at odds with current popular theories on individual rights.

During the drafting of early constitutions, individuals were seen as important because of the prevalent idea of creating equality through equal and standard rights for everyone. ${ }^{44}$ If rights were afforded to one group but not another, this would be considered unfair treatment. ${ }^{45}$ However, in reality, shortcomings exist when we live in a world where certain groups are discriminated against for many reasons. ${ }^{46}$

Furthermore, liberalism is based upon notions that individuals assert rights. However, many times it is groups, especially majority groups, who are asserting them so

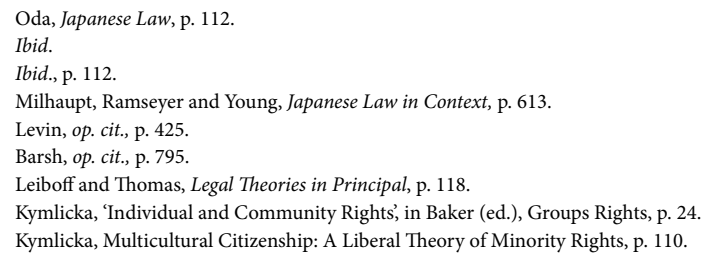


that the majority culture is preserved. ${ }^{47}$ Therefore, the minority groups of people are not equal because of their membership with a particular group. If people have an advantage because they were born into a particular group then the original ideas of liberalism are undermined due to the abundance of accommodation to the majority group. ${ }^{48}$ This imbalance often needs to be rectified to make people equal and this can only be done by implementing some form of collective rights. ${ }^{49}$ As a result, collective rights do not necessarily equate to unfair treatment for people not afforded them and can actually assist in ensuring that equality is protected in areas where the group is disadvantaged. The ruling in the Nibutani Dam Case inherently recognised this point in its recognition of the Ainu people as an indigenous group, rather than just a minority group. The rights recognised could be different according to indigenous needs.

The Nibutani Dam Case ruling pointed out that the Ainu had been subject to a number of adverse policies under the Japanese Meiji Government and discrimination still lingered today. The judgement asserted that there was a need to protect the dying culture of the Ainu and that there was an obligation on the part of the legal system to recognise this. ${ }^{50}$ Thus, the ruling concluded that collective rights arose from the ongoing discrimination against the Ainu. These collective rights were also necessary to protect Ainu individuals' right to pursue happiness through their unique culture. ${ }^{51}$ Some theorists have elaborated on this by arguing that collective identification and protection is important for an individual's pursuit of happiness; thus, the two become intertwined, as one needs a collective dimension of rights to satisfy the fundamental individual right. ${ }^{52}$

For the specific case of the Ainu, if collective rights in the various drafts of the Declaration on the Rights of Indigenous Peoples were to exist in Japan for them, then this would also assist in achieving equality as defined by liberalist principles. The Ainu have been subject to a number of historically discriminatory practices that have deprived them of traditional land and cultural practices. There is an assertion of rights by the majority of Japanese in simple things, such as the right to use the Japanese language rather than the Ainu language. Collective rights would enable some form of protection against further deterioration of the Ainu situation. Inequalities that arise from one being an Ainu need to be addressed in a collective manner for true equality. Collective and individual rights are not distinct from one another and the existence of one does not make the other an invalid concept. Thus, for the Ainu, the recognition in

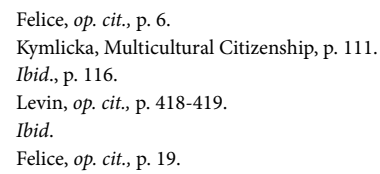


.

Japan of collective rights should be a possibility in spite of the Japanese government's resistance to the idea. Furthermore, the Japanese government's stance on collective rights is becoming more isolated as collective rights become more mainstream in the international community and are included in more international instruments. The Declaration on the Rights of Indigenous Peoples is the latest material that progresses this trend of including collective rights.

\section{International Collective Rights}

Collective rights are widespread in international conventions and declarations. The United Nations' first and most important declaration, the Declaration on Human Rights, was based upon liberalist ideas and deals mostly with individuals as holders of certain rights. ${ }^{53}$ However, within the United Nations today there is a wide variety of references to rights held by groups. The Declaration on the Rights of Indigenous Peoples is just one international agreement that makes mentions of rights that are specifically collective..$^{54}$ Collective rights also feature prominently in the International Labour Organisation's Convention concerning Indigenous and Tribal Peoples in Independent Countries. ${ }^{55}$ Collective rights are found in these agreements because to create equality for indigenous peoples, collective protection is necessary. However, this collective protection of minority rights has not always been prevalent.

The International Convention on Civil and Political Rights was originally specific to individual rights. ${ }^{56}$ Yet, it was this convention that was cited in the Nibutani Dam Case to establish the Ainu's rights as collective ones. ${ }^{57}$ Article 27 of the convention is relevant to 'persons belonging to' minorities, not the minority groups themselves. The Sapporo District Court referred to the International Covenant on Civil and Political Rights as an instrument to protect the rights of individuals to ensure their equality, ${ }^{58}$ much like the original aims of liberalism. Nevertheless, a more expansive understanding was employed in the Nibutani Dam Case ruling, where it found the Ainu, as a minority group, had rights as a whole. They did this by recognising that the Ainu could be defined as a minority group under article 27 because they possess a distinct culture as the article describes. ${ }^{59}$ The court went further to investigate the historical relationship between the Ainu and the ethnic Japanese in order to determine that the Ainu were indigenous and needed to be treated in a collective manner. This was important to proving the

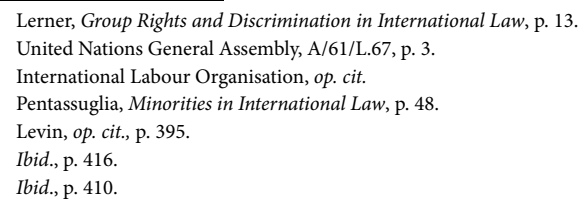


significance of the Nibutani Dam site to the Ainu as a people. The court emphasised the aim to protect minority groups in the International Covenant on Civil and Political Rights and as a result asserted that the use of this convention should not be limited. ${ }^{60}$

Furthermore, the court pointed out that the guarantees of certain rights included in the Japanese Constitution are subject to individual dimensions of rights. However, if individuals were subject to certain limits in their right to their own culture, then their right to pursue happiness was hindered by the majority of individuals who constitute the state. So the rights of these individuals were not being protected on account of their minority group status. ${ }^{61}$ Consequently, the court allowed ideas of collective rights to apply to the Ainu. This is a direct example of how collective rights can be used to assist in protecting individual rights and how these collective rights can arise out of individual rights.

Many other legal instruments apply more specifically to indigenous people. Perhaps, one of the most significant of these is the International Labour Organisation's Convention concerning Tribal and Indigenous People in Independent Countries. This convention is important for two main reasons: it provides a definition of what indigenous people are, and it states several rights that arise from a groups' indigenous status. The convention is collective in nature, as is the importance of collective rights for indigenous people. ${ }^{62}$

The Declaration on the Rights of Indigenous Peoples is the next step as collective indigenous rights become more widespread in international instruments. For indigenous rights to have significance in Japan, collective rights need to be recognised. However, for the Ainu people, it is clear that the government controls interpretations of the Constitution and the Declaration on the Rights of Indigenous Peoples in a manner contradictory to international standards. Thus, the government's reasons to deny rights are central to furthering the declaration. As a result, possible motives of rejecting rights need to be explored.

\section{Japan and the Ainu}

Japan's refusal to protect collectively the rights of the Ainu people has little to do with the strength of the Constitution. Rather, the limitations of collective rights for Ainu can be attributed to the attitude of the Japanese government itself.

\footnotetext{
Ibid., pp. 417-418.

61 Ibid.

62 International Labour Organisation, op. cit.
} 
.

One of the most important collective rights for the Ainu is the right to selfdetermination. As such, the actions of the Japanese government in the past have shown a pattern of opposing self-determination. For example, preliminary talks on the Ainu Shinpō did not include any government support for self-determination in spite of calls from Ainu groups for such a provision. ${ }^{63}$ Likewise, in 2007, the Japanese representative stressed that self-determination did not mean that indigenous people were in any way separate from the state and asserted that collective self-determination cannot exist. ${ }^{64}$ Thus, self-determination has long been a pivotal aspect of indigenous rights that Japan seemingly does not want to concede.

While self-determination may be integral to one's indigenousness, it is not essential to proving one's indigenousness. It plays a more important role because it is a right generally seen as important to those who are indigenous. ${ }^{65}$ This is because the right to determine affairs on behalf of a minority group in a particular country must come from a form of disadvantage, mainly one that relates to prior lack of control over affairs. Thus, it has become an essential issue for indigenous groups who demand equal rights. ${ }^{66}$

Furthermore, self-determination can only be furthered in a collective manner, not an individual one. Therefore, the Ainu are asking for collective rights when they demand self-determination. For Japan to deny collective rights, they are not allowing any degree of self-determination. Not allowing a notion of collective rights to exist has a significant impact on other rights as well, most importantly land rights.

Japan has ignored issues of land rights but this is somewhat different in other parts of the world. Compared to various other countries, Japan's Ainu Cultural Promotion Act does relatively little for the population, as indigenous rights are generally comprised of cultural, land and self-determination rights. ${ }^{67}$ However, the Ainu Shinpo deals solely with cultural aspects of the Ainu.

Japan's attitude to the Ainu may seem surprising when one considers the impact of the Ainu in Japan itself. The Ainu are a relatively small group within Japan. Their official numbers are listed at less than 25,000 (although Ainu lobby groups estimate their numbers larger than this). ${ }^{68}$ However, in the 1995 discussions on the Draft Declaration on the Rights of Indigenous Peoples, Japan was one of the countries most resistant to the articles contained in the draft. This negative reaction seems at odds with the relatively

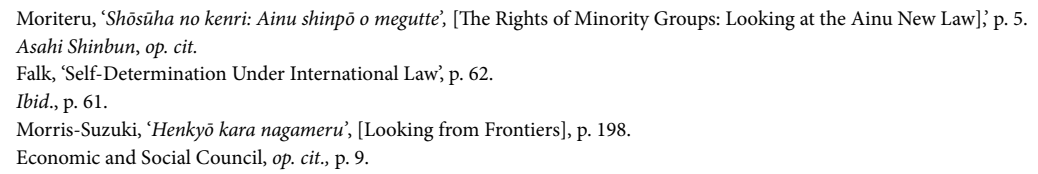


small number of indigenous people in Japan. Other countries, such as Canada and Australia, with much larger indigenous populations have made efforts to address land rights after landmark court cases. ${ }^{69}$ However, Japan has not considered the issue of Ainu receiving any land since the 1899 Former Natives Protection Act, in which land was only given on the condition that Ainu people use it for farming.

The Nibutani Dam Case was essentially a case involving land and its importance to each of the parties. The Ainu declared that the land was an important aspect of their culture as many rituals take place in certain areas that the dam would abolish. ${ }^{70}$ The significance of this argument is that a relationship to land is an essential aspect of being indigenous. Internationally accepted definitions of indigenous refer to the land as being an integral part to proving one's indigenousness.

The Japanese government has been very reluctant to accommodate any form of land and self-determination rights for the Ainu; rights which are typically afforded to indigenous groups. The government has attempted to steer the attention of rights for the Ainu into the cultural aspects contained in the 1997 Ainu Shinpō. By doing this, the government is effectively able to emphasise the non-indigenous characteristics of the Ainu so that they are treated the same as other minority groups. Furthermore, Japan also had objections to an individual's right to self-identify as indigenous. Why would these be so important to Japan if denying collective rights might leave the Ainu with only the right to be recognised as indigenous but with no further assistance or special treatment?

When considering the Ainu Shinpō, the government wrote that the Ainu are only native to Japan's 'inalienable land'. ${ }^{71}$ The usage of this term suggests that Ainu and Ainu Moshir (traditional Ainu land) have always made up one part of Japan's territorial landscape. It also implies that the Ainu and the ethnic Japanese comprise a single identity of 'Japan', of which they are both a part. This was similar to the stance of the Chinese Government at the discussions of the 1995 draft declaration.

The Chinese representative put forward the suggestion that the indigenous populations identified in Asia were not in fact indigenous because they were not subject to alien values and cultures from overseas. Thus, they are not indigenous, but are rather national minorities. ${ }^{72}$ Japan joined in China's call to include a definition of indigenous people that could ignore colonisation in Asia. However, this belief in the existence of simple national minorities is based on a falsehood that these minority groups have always

\footnotetext{
Morris-Suzuki, op. cit., p. 198.

Levin, op. cit., p. 411.

Siddle, 'An epoch-making event? The 1997 Ainu Cultural Promotion Act and it's impact', p. 408.

Close and Askew, Asia Pacific and Human Rights: A Global Political Economy Perspective, p. 167.
} 
.

been part of the national boundaries. While the ethnic Japanese are widely considered to be the original inhabitants of most of Japan, they cannot truthfully claim a historical existence of a shared Japanese identity and peaceful co-habitation with the Ainu. To ignore issues of colonisation, Japan is able to manipulate the international definitions of indigenous so that they do not apply to the Ainu. This is because, if it were the case that the Ainu were never subject to colonisation or the taking of land, then international definitions of indigenous do not apply to the Ainu. By minimising the admission of colonisation, Japan can limit claims of land rights and how they relate to being defined as indigenous. This is important for Japan because of several reasons.

The Ainu are in a unique situation as their traditional land is divided by the current borders of Japan and Russia. Hokkaido is part of Japan; however, the Kuril Islands and Sakhalin are Russian Territory. This Russian owned territory has been the source of a lot of debate in Japan, as the government has long been insistent that all of these territories belong to Japan. According to the government, this is because these islands have always been Japan's. ${ }^{73}$ Consequently, the government would also need to show that Ainu have always been Japanese. Thus, the limitation of indigenous recognition becomes important.

Japan's unwillingness to accommodate the Ainu may be in part due to what Ainu land represents to the government. Japan's most recent statement at the 2007 discussions of the draft declaration appears to confirm this. In 2007, the Japanese representative specifically noted that indigenous rights would not impair a state's territorial integrity. ${ }^{74}$ Thus, the issue of the Northern Territories becomes a central point. If the Ainu were to be recognised as indigenous to the whole of Ainu Moshir, this would include not only the area of Hokkaido but also the area that is now known as the Northern Territories. This would contradict Japan's assertion that the area has always been Japanese. However, as little progress is made on both issues the complexities of any relationship cannot fully be explored.

\section{Conclusion}

The Declaration on the Rights of Indigenous Peoples has undergone many changes. Much like the Ainu Shinpō, which started as a radical idea and ended up as an with limited relief for the Ainu, the Declaration on the Rights of Indigenous Peoples may suffer a similar fate. This declaration has gone from an instrument that promised selfdetermination and land rights to one that allows state control over interpretations of

Kimura and Welsh, 'Specifying "Interests": Japan's Claim to the Northern Territories and Its Implications for International Relations Theory', p. 230.

74 United Nations General Assembly, GA/10612. 
its provisions and the protection of state unity. For the case of Japan, the inclusion of collective rights has been a central point of contention during the drafting process. Without collective rights, self-determination and land rights are extinguished. Thus, the government is able to focus on more typical minority rights relating to culture, accentuating the Ainu's minority status rather than their indigenous status. This emphasis on minority status is further promoted by the Japanese government's insistence that indigenous definitions do not exist in international instruments.

Thus, in spite of the United Nations adopting the Declaration on the Rights of Indigenous Peoples, indigenous rights may continue to have little influence in Japan. The Japanese government has reacted mostly negatively to the Declaration under the guise of protecting individual rights in Japan. However, an analysis of this stance reveals it to be shallow and unjustified. The Japanese Constitution is clearly not the reason why indigenous rights cannot exist in Japan, nor is the lack of international definitions of indigenous. Therefore, the Japanese government must be held accountable for the denial of these rights. It is clear that the lack of collective and therefore indigenous rights is not due to the provisions within the Japanese Constitution. The Japanese government is very purposefully rejecting indigenous rights and because of this, the implemented Declaration on the Rights of Indigenous Peoples will have little impact in Japan. By not allowing collective rights but also indigenous recognition, the government is concentrating largely on any rights that could make the Ainu distinct from other national minorities.

The Japanese government has a strong motive for denying the Ainu the right to call themselves indigenous, namely the Northern Territories issue. Indigenous rights of land and self-determination can only hinder Japan's effort to assert control over the Northern Territories as the issue itself is both a political and land one. Cultural rights, however, have little to do with this issue and therefore can be afforded more readily under the Ainu Shinpō. Thus, perhaps until the issue of the Northern Territories is solved, the Ainu will seemingly continue to be denied indigenous recognition that acknowledges colonisation. In spite of significant worldwide progress, the Ainu situation may remain static in the near future.

\section{References}

African Group, Draft Aide Memoir, Retrieved 08 August 2007, from http://www.iwgia.org/graphics/Synkron-Library/ Documents/InternationalProcesses/DraftDeclaration/AfricanGroupAideMemoireOnDeclaration.pdf.

African Group, United Nations Declaration on the Rights of Indigenous Peoples, Retrieved 26 July 2007, from http://www. ishr.ch/hrm/nymonitor/new_york_updates/african_text_draft_8_may_2007.pdf. 
New Voices Volume 2

Asahi Shinbun, 'Senjuminzoku kenri sengen wo saitaku', [The Declaration on Indigenous People is adopted at the end of more than 20 years of debates at the United Nations]', Asahi Shinbun, Retrieved 16 September 2007, from http://www.asahi.com/international/update/0914/TKY200709140065.html.

Barsh, R. L.,'Indigenous People and the UN Commission on Human Rights: A Case of the Immovable Object and the Irresistible Force, Human Rights Quarterly, 18, 4 (1996), pp. 782-808.

Close, P. and Askew, D., Asia Pacific and Human Rights: A Global Political Economy Perspective, (England; USA: Ashgate, 2004).

Corntassel, J., 'Partnership in Action? Indigenous Political Mobilisation and Co-optation During the First UN Indigenous Decade (1995-2004)', Human Rights Quarterly, 29 (2007), pp. 137-166.

Economic and Social Council, 'Racism, Racial Discrimination, Xenophobia and All Forms of Discrimination', Document E/CN.4/2006/16/Add.2, Retrieved 5 May 2007, from http://www.universalhumanrightsindex.org/ documents/832/774/document/en/pdf/text.pdf.

Falk, R., 'Self-Determination Under International Law', in Danspeckgruber, W. (ed.), The Self-Determination of Peoples: Community Nation and State in an Independent World, (London: Lynne Rienner, 2002), pp. 31-66.

Felice, W., Taking suffering seriously: the importance of collective human rights, (Albany: State University of New York Press, 1996).

Human Rights Council, 'Human Rights Council adopts texts for protection from forced disappearance, rights of indigenous people', Release HRHRC06026E, Retrieved 10 October 2006, from http://www.ifg.org/pdf/ UN\%20human\%20rights.pdf.

Human Rights Council, 'Implementation of General Assembly Resolution 60/251 of March 152006 entitled "Human Rights Council”, annex to United Nations General Assembly document A/HRC/1/L.3, 23/06/2006, Retrieved 8 September 2006, from http://www.un.org.

International Labour Organisation, Convention (No. 169) Concerning Indigenous and Tribal Peoples in Independent Countries, (1989), Retrieved 3 April 2007, from http://www.ilo.org/ilolex/cgi-lex/convde.pl?C107.

Kimura, M. and Welsh, D., 'Specifying "Interests": Japan's Claim to the Northern Territories and Its Implications for International Relations Theory', International Studies Quarterly, 42 (1998), pp. 213-244.

Kymlicka, W., 'Individual and Community Rights' in Baker, J. (ed), Groups Rights, (Toronto, Buffalo, London: University of Toronto Press, 1992).

Kymlicka, W., Multicultural Citizenship: A Liberal Theory of Minority Rights, (Oxford and New York: Clarendon Press, 1995).

Leiboff, M. and Thomas, M., Legal Theories in Principal, (Sydney: Lawbook Co., 2004).

Lerner, N., Group Rights and Discrimination in International Law, (The Hague, London, New York: Matinus Nijhoff Publishers, 2003).

Levin, M., 'Kayano et. al v. Hokkaido Expropriation Committee (The Nibutani Dam Decision),' International Legal Materials, 38 (1999), pp. 394-429. 
Milhaupt, C. J., Ramseyer, J. M., and Young, M. K., Japanese Law in Context: Readings in Society, the Economy and Politics, (United States of America: Harvard University Asia Centre, 2001).

Moriteru, A., 'Shōsūha no kenri: Ainu shinpō o megutte', [The Rights of Minority Groups: Looking at the Ainu New Law]', Jurisuto, 941 (1989), p. 5.

Morris-Suzuki, T., 'Collective Memory, Collective Forgetting: Indigenous People and the Nation state in Japan and Australia' Meanjin, 53, 4 (1994), pp. 487-612.

Morris-Suzuki, T., 'Henkyō kara nagameru', [Looking from Frontiers], (Tokyo: Misuzu Shobo, 2000).

Oda, H., Japanese Law, (United Kingdom: Butterworths, 1992).

Pentassuglia, G., Minorities in International Law, (Germany: Council of Europe, 2002).

Siddle, R., 'An epoch-making event? The 1997 Ainu Cultural Promotion Act and it's impact', Japan Forum, 14, 3 (2002), pp. 405-423.

Siddle, R., 'The Limits to Citizenship in Japan: Multiculturalism, Indigenous Rights and the Ainu,' Citizenship Studies, 7 , 4 (2003), pp. 447-462.

Siddle, R., Race, Resistance and the Ainu of Japan, (London, New York: Routledge, 1996).

Sub-Commission on Prevention of Discrimination and Protection of Minorities, 'Draft United Nations Declaration on the Rights of Indigenous People', annex to document E/CN.4/Sub.2/1994/56, Retrieved 24 February 2007, from http://www.unhchr.ch/huridocda/huridoca.nsf/(Symbol)/E.CN.4.SUB.2.RES.1994.45.En.

United Nations, 'Namibia: amendments to draft resolution A/C.3/61/L.18/Rev.1', document A/C.3/61/L.57/Rev.1, Retrieved 25 February 2007, from http://www.daccessdds.un.org/doc/UNDOC/LTD/N06/612/32/PDF/ N0661232.pdf?OpenElement.

United Nations General Assembly, 'Declaration on the Rights of Indigenous Peoples', Document A/61/L.67, Retrieved 15 September 2007, from http://www.daccessdds.un.org/doc/UNDOC/LTD/N07/498/30/PDF/N0749830. pdf?OpenElement.

United Nations General Assembly, Declaration on the Rights of National or Ethnic, Religious and Linguistic Minorities, Retrieved 5 July 2007, from http://www.ohchr.org/english/law/minorities.htm.

United Nations General Assembly, 'General Assembly adopts Declaration on the Rights of Indigenous Peoples; 'major step forward' for human rights for all, says President,' Release GA/10612, Retrieved 15 September 2007, from http://www.un.org/News/Press/docs/2007/ga10612.doc.htm. 